\title{
Evolutionary impacts of fishing: overfishing's 'Darwinian debt'
}

\author{
John M Pandolfi
}

\author{
Address: ARC Centre of Excellence for Coral Reef Studies, Centre for Marine Studies, and School of Earth Sciences, University of Queensland, \\ Brisbane, QLD 4072, Australia \\ Email: j.pandolfi@uq.edu.au
}

FI000 Biology Reports 2009, I:43 (doi:I0.34I0/BI-43)

The electronic version of this article is the complete one and can be found at: http://FI000.com/Reports/Biology/content/I/43

\begin{abstract}
Human harvesting of fish results in far greater mortality than natural causes, with enormous potential to affect the phenotypic traits of fish populations, even after exploitation stops. Central to understanding these effects is the untangling of the genetic versus environmental components of phenotypic response. Evolutionary consequences of harvesting must be incorporated into conservation and management strategies.
\end{abstract}

\section{Introduction and context}

Harvesting by humans is widely recognized to exert significant evolutionary changes in wild populations $[1,2]$. Rates of phenotypic change in harvested populations can exceed those in their 'natural' counterparts by as much as $300 \%$ [3]. Because of the significant depletion in many of the world's fisheries [4], there is now considerable interest in fisheries-induced evolution (FIE) [5-8] from both an evolutionary [9] and a conservation [5] perspective. Fisheries have been associated with a plethora of phenotypic changes in wild fish populations [9-11], manifested in changes in growth $[12,13]$, reproduction $[14,15]$, morphology [16], physiology and behaviour $[17,18]$, and life history traits such as size and age at maturation [13,19-24]. Modelling studies have also predicted fisheries-induced changes in both life history traits [25] and spawning migration strategy [26]. The evolution of traits that genetically covary with those under direct selection can also influence the rate of evolution occurring by exploitation alone [27]. FIE has even been invoked to explain vulnerability to recreational fishing $[28,29]$.

Despite the weight of evidence for phenotypic change induced by fishing, it is generally accepted that unequivocal empirical evidence of underlying genetic change resulting from fishing is lacking $[9,30]$, though tantalizing experimental evidence is highly suggestive $[17,31]$.
The crux of the problem is that changes in fish density and the environment can act to drive phenotypic plasticity in the absence of any genetic response attributable to selection [32,33]. However, there is also widespread acceptance of the notion that fishing causes a change in the selective regime of wild stocks, so that evolutionary change should be inevitable [34]. The implications are far-reaching; seemingly minimal shifts in age at maturity (say from 6 to 4 years in Atlantic cod) can result in reduced annual population growth by up to $30 \%$, and a doubling in the probability of negative population growth [35]. One of the most promising techniques for understanding the genetic contribution to phenotypic change is probabilistic reaction norms for maturation (PRNM) - the fish's probability of maturing as a function of its age and size $[23,36,37]$.

\section{Major recent advances}

Important recent work is helping to quantify selection responses to overfishing, where there has been a dearth of data [38]. The study of Atlantic cod from Canada's Southern Gulf of St Lawrence stands out for estimating selection from an exploited stock [13]. Sexual selection might also be involved in altering the rate of evolutionary change by fishing [39]. A logical question stems from this work - how much evolution is caused by natural selection and how much is harvest-induced? Are these opposing forces or do they work synergistically $[40,41]$ ? 
Recent studies suggest that fisheries-induced selection acts against and tends to swamp natural selection, leading to changes in populations that may take a long time, if ever, to reverse [42].

In fact, rates of reversibility in 'evolutionary changes' due to FIE could be extremely low even after fishing pressure ceases $[13,42]$, especially when there has been major depletion of fish stocks due to over-exploitation, resulting in lower heritable genetic variation. Such is not surprising in light of the fact that fishing can result in fish mortality far greater than natural mortality - by more than $400 \%$, resulting in far greater selection differentials $[43,44]$. The phenomenon in which current levels of exploitation will require several years of evolutionary recovery has been termed by $U$ Dieckmann as the 'Darwinian debt' [45], which will need to be paid by future generations. Earlier studies showed a reduction in the ability of populations to recover [46] so FIE might keep resilience of fish populations low for long periods [27]. However, a recent laboratory study demonstrated evolutionary reversibility, despite full recovery taking up to 12 generations in fish with an annual life cycle, (equivalent to 36-84 years in typical harvested fish that have generation times of 3-7 years) [31]. Decadal scales of recovery mean we still need to consider evolution in fisheries management [31].

\section{Future directions}

One of the biggest challenges for proponents of the theory of FIE is to disentangle genetic changes from environmental changes - even PRNM do not yet have strong empirical support [7]. But does this matter? Only in the sense that evolutionary changes could take longer to recover from once fishing pressure is reduced, as now appears to be the case [31]. So another key question arises as to how quickly FIE occurs in fish stocks [7]. If it occurs on a scale of years to decades, then it is much more relevant to fisheries management than if it occurs on a centennial scale.

Because it is so widespread and potentially harmful, there is justified and increasing interest in FIE to be incorporated into ecosystem-based management of fisheries worldwide [5,47-49]. Some authors are even calling for the adoption of 'evolutionary impact assessments' [5]. Others have used FIE to stress the recent recommendation of keeping the larger fish around $[7,8,50]$. But it must also be stressed that effects of FIE are variable and, where they occur, might be managed effectively [51]. Experimental studies confirm recovery from FIE after selection regimes have been relaxed in the laboratory [31], supporting the notion that genetic diversity loss does not necessarily accompany FIE. Evolutionary scientists will need to work more closely with managers to incorporate FIE into conservation management [52].

The consequences of FIE are many and daunting considering the importance of life history traits to population dynamics, biomass, demography and economic yield [5]. FIE may also lead to reduced productivity [12], lower maximum sustainable yields [12], slower rates of population growth, and lower probabilities of recovery [46]. As such, further research should focus on the demographic consequences of FIE over multiple temporal scales [8]. While the field is exciting and changing almost daily, we still have very little information of how species are affected by FIE, and the extent to which various traits are vulnerable.

\section{Abbreviations}

FIE, fisheries-induced evolution; PRNM, probabilistic reaction norms for maturation.

\section{Competing interests}

The author declares that he has no competing interests.

\section{Acknowledgements}

Thanks to Christopher Brown (The Ecology Centre, University of Queensland and CSIRO Marine and Atmospheric Research) and three anonymous reviewers for their comments on the manuscript.

\section{References}

I. Palumbi SR: Evolution - Humans as the world's greatest evolutionary force. Science 200I, 293:I786-90.

2. Allendorf FW, England PR, Luikart G, Ritchie PA, Ryman N: Genetic effects of harvest on wild animal populations. Trends Ecol Evol 2008, 23:327-37.

3. Darimont CT, Carlson SM, Kinnison MT, Paquet PC, Reimchen TE, Wilmers CC: Human predators outpace other agents of trait change in the wild. Proc Natl Acad Sci U S A 2009, 106:952-4.

FI000 Factor 3.0 Recommended Evaluated by J Emmett Duffy I0 Feb 2009

4. Lotze HK, Worm B: Historical baselines for large marine animals. Trends Ecol Evol 2009, 24:254-62.

5. Jørgensen $C$, Enberg $K$, Dunlop ES, Arlinghaus R, Boukal DS, Brander K, Ernande B, Gardmark A, Johnston F, Matsumura S, Pardoe H, Raab K, Silva A, Vainikka A, Dieckmann U, Heino M, Rijnsdorp AD: Ecology - managing evolving fish stocks. Science 2007, 3 1 8: 1247-8.

6. Kuparinen A, Merila J: Detecting and managing fisheriesinduced evolution. Trends Ecol Evol 2007, 22:652-9.

7. Law R: Fisheries-induced evolution: present status and future directions. Mar Ecol Prog Ser 2007, 335:27I-7.

8. Hutchings JA, Fraser DJ: The nature of fisheries- and farminginduced evolution. Mol Ecol 2008, I7:294-3 I3.

9. Hard J, Gross MR, Heino M, Hilborn R, Kope RG, Law R, Reynolds JD: Evolutionary consequences of fishing and their implications for salmon. Evol Appl 2008, I:388-408.

10. Fenberg PB, Roy K: Ecological and evolutionary consequences of size-selective harvesting: how much do we know? Mol Ecol 2008, I 7:209-20. 
II. Hendry AP, Farrugia T], Kinnison MT: Human influences on rates of phenotypic change in wild animal populations. Mol Ecol 2008, 17:20-9.

12. Conover DO, Munch SB: Sustaining fisheries yields over evolutionary time scales. Science 2002, 297:94-6.

13. Swain DP, Sinclair AF, Hanson JM: Evolutionary response to sizeselective mortality in an exploited fish population. Proc Biol Sci 2007, 274:1015-22

FI000 Factor 3.2 Recommended

Evaluated by Mikko Heino 27 Mar 2007, J Emmett Duffy 25 May 2007

14. Rijnsdorp AD, Grift RE, Kraak SBM: Fisheries-induced adaptive change in reproductive investment in North Sea plaice (Pleuronectes platessa)? Can J Fish Aquat Sci 2005, 62:833-43.

15. Thomas G, Quoss H, Hartmann J, Eckmann R: Human-induced changes in the reproductive traits of Lake Constance common whitefish (Coregonus lavaretus). J Evol Biol 2009, 22:88-96.

16. Hamon TR, Foote CJ, Hilborn RAY, Rogers DE: Selection on morphology of spawning wild sockeye salmon by a gill-net fishery. Trans Am Fish Soc 2000, 129: I300-I5.

17. Biro PA, Post JR: Rapid depletion of genotypes with fast growth and bold personality traits from harvested fish populations. Proc Natl Acad Sci U S A 2008, 105:2919-22.

FI000 Factor 3.0 Recommended

Evaluated by Robert Paine 13 Mar 2008

18. Uusi-Heikkilä S, Wolter C, Klefoth T, Arlinghaus R: A behavioral perspective on fishing-induced evolution. Trends Ecol Evol 2008, 23:419-2I.

19. Olsen EM, Heino M, Lilly GR, Morgan MJ, Brattey J, Ernande B, Dieckmann U: Maturation trends indicative of rapid evolution preceded the collapse of northern cod. Nature 2004, 428:932-5.

20. Olsen EM, Knutsen H, Gjøsæter J, Jorde PE, Knutsen JA, Stenseth NC: Small-scale biocomplexity in coastal Atlantic cod supporting a Darwinian perspective on fisheries management. Evol Appl 2008, I:524-33.

21. Reznick DN, Ghalambor CK: Can commercial fishing cause evolution? Answers from guppies (Poecilia reticulata). Can J Fish Aquat Sci 2003, 62:791-801.

22. Morita K, Fukuwaka M: Why age and size at maturity have changed in Pacific salmon. Mar Ecol Prog Ser 2007, 335:289-94.

23. Dieckmann $U$, Heino M: Probabilistic maturation reaction norms: their history, strengths, and limitations. Mar Ecol Prog Ser 2007, 335:253-69.

24. Hutchings JA, Baum JK: Measuring marine fish biodiversity: temporal changes in abundance, life history and demography. Phil Trans R Soc B 2005, 360:3 I5-38.

25. Thériault $V$, Dunlop ES, Dieckmann $U$, Bernatchez L, Dodson JJ: The impact of fishing-induced mortality on the evolution of alternative life-history tactics in brook charr. Evol Appl 2008, I:409-23.

26. Jørgensen C, Dunlop ES, Opdal AF, Fiksen O: The evolution of spawning migrations: state dependence and fishing-induced changes. Ecology 2008, 89:3436-48.

27. de Roos AM, Boukal DS, Persson L: Evolutionary regime shifts in age and size at maturation of exploited fish stocks. Proc Biol Sci 2006, 273:1873-80.

28. Cooke SJ, Suski CD, Ostrand KG, Wahl DH, Philipp DP: Physiological and behavioral consequences of long-term artificial selection for vulnerability to recreational angling in a teleost fish. Physiol Biochem Zool 2007, 80:480-90.

29. Philipp DP, Cooke SJ, Claussen JE, Koppelman JB, Suski CD, Burkett DP: Selection for vulnerability to angling in largemouth bass. Trans Am Fish Soc 2009, 138:189-99.

30. Waples RS, Hendry AP: Special Issue: Evolutionary perspectives on salmonid conservation and management. Evol Appl 2008, I:183-8.
31. Conover DO, Munch SB, Arnott SA: Reversal of evolutionary downsizing caused by selective harvest of large fish. Proc Biol Sci 2009, 276:2015-20.

32. Heino M, Baulier L, Boukal DS, Dunlop ES, Eliassen S, Enberg K, Jørgensen C, Varpe O: Evolution of growth in Gulf of St Lawrence cod? Proc Biol Sci 2008, 275: I I I I-2.

33. Swain DP, Sinclair AF, Hanson JM: Evolution of growth in Gulf of St Lawrence cod: reply to Heino et al. Proc Biol Sci 2008, 275: III3-5.

34. Naish KA, Hard J]: Bridging the gap between the genotype and the phenotype: linking genetic variation, selection and adaptation in fishes. Fish Fisheries 2008, 9:396-422.

35. Hutchings JA: Life history consequences of overexploitation to population recovery in Northwest Atlantic cod (Gadus morhua). Can J Fish Aquat Sci 2005, 62:824-32.

36. Heino M, Dieckmann U, Godo OR: Estimating reaction norms for age and size at maturation with reconstructed immature size distributions: a new technique illustrated by application to Northeast Arctic cod. ICES J Mar Sci 2002, 59:562-75.

37. Heino M, Dieckmann U, Godo OR: Measuring probabilistic reaction norms for age and size at maturation. Evolution 2002, 56:669-78.

38. Brown CJ, Hobday AJ, Ziegler PE, Welsford DC: Darwinian fisheries science needs to consider realistic fishing pressures over evolutionary time scales. Mar Ecol Prog Ser 2008, 369: 257-66.

39. Hutchings JA, Rowe S: Consequences of sexual selection for fisheries-induced evolution: an exploratory analysis. Evol Appl 2008, I: 129-36.

40. Carlson SM, Edeline E, Asbjørn Vøllestad L, Haugen TO, Winfield IJ, Fletcher JM, Ben James J, Stenseth NC: Four decades of opposing natural and human-induced artificial selection acting on Windermere pike (Esox lucius). Ecol Lett 2007, 10:5 I2-2I.

4I. Edeline E, Carlson SM, Stige LC, Winfield IJ, Fletcher JM, James JB, Haugen TO, Vøllestad LA, Stenseth NC: Trait changes in a harvested population are driven by a dynamic tug-of-war between natural and harvest selection. Proc Natl Acad Sci U S A 2007, 104:15799-804.

42. Law R, Grey DR.: Evolution of yields from populations with age-specific cropping. Evol Ecol 1989, 3:343-59.

43. Law R, Rowell CA: Cohort-structured populations, selection responses, and exploitation of the North Sea cod. In The Exploitation of Evolving Resources: Proceedings of an International Conference, Held at Julich, Germany, September 3-5, 1991. Edited by Stokes TK, McGlade JM, Law R. Berlin: Springer-Verlag; 1993, I55-I 73.

44. Mertz G, Myers RA: A simplified formulation for fish production. Can J Fish Aquat Sci 1998, 55:478-84.

45. Cookson C: Over-fishing produces a Darwinian revenge as only smaller cod survive. Financial Times 2004, Aug 28.

46. Walsh MR, Munch SB, Chiba S, Conover DO: Maladaptive changes in multiple traits caused by fishing: impediments to population recovery. Ecol Lett 2006, 9:142-8.

47. Francis RC, Hixon MA, Clarke ME, Murawski SA, Ralston S: Fisheries management - Ten commandments for ecosystem-based fisheries scientists. Fisheries 2007, 32:217-233.

48. Guttormsen AG, Kristofersson D, Naevdal E: Optimal management of renewable resources with Darwinian selection induced by harvesting. J Environ Econ Manage 2008, 56:167-79.

49. Longhurst A: Viewpoint - The sustainability myth. Fish Res 2006, 81:107-12.

50. Birkeland C, Dayton PK: The importance in fishery management of leaving the big ones. Trends Ecol Evol 2005, 20:356-8.

5I. Hilborn R, Minte-Vera CV: Fisheries-induced changes in growth rates in marine fisheries: Are they significant? Bull Mar Sci 2008, 83:95-105.

52. Waples RS, Punt AE, Cope JM: Integrating genetic data into management of marine resources: how can we do it better? Fish Fisheries 2008, 9:423-49. 